\title{
The Metanarraphors We Lead and Mediate by: Insights from Cognitive Metaphor Theory in the Context of Mediation in a VUCA World
}

\author{
Jacobus (Kobus) Kok and Barney Jordaan
}

\begin{abstract}
We live in a superdiverse and supermobile world which is Volatile, Uncertain, Complex and Ambiguous (VUCA). Diversity management, social cohesion, mediation and negotiation skills are needed in such times. In all discourses, within the context of leading and facilitating the resolution of disputes metaphorical frameworks of meaning are created. The challenge for the mediator is to become aware of, and keep in mind how metaphors affect the process of mediation and the mediator's own role in it. Those unaware of the dynamics of metaphor theory might implicitly be limited in the mediation process due to the socio-cognitive confines and frames of the metaphors being used in a given mediation context. By becoming aware of the dynamics of metaphor, by means of critically reflecting on metaphor theory, that which is often overt in the mediation dynamics, could be reflected upon covertly. This in turn will empower not only the mediator, but also the parties to a conflict or dispute as they reflect critically on the "metanarraphors" (meta-narratives and metaphors) they mediate or are influenced by.
\end{abstract}

The original version of this chapter was revised. A correction to this chapter is available at https://doi.org/10.1007/978-3-319-98884-9_13.

J. (Kobus) Kok ( $\square)$

Department of New Testament, Evangelische Theologische Faculteit, Leuven, Belgium

Extraordinary Professor, University of Pretoria, Pretoria, South Africa

Research Associate (Classical Studies) at the University of the Free State, Bloemfontein, South Africa

e-mail: kobus.kok@etf.edu

B. Jordaan $(\varangle)$

Management Practice, Vlerick Business School, Ghent, Belgium

University of Stellenbosch Business School, Cape Town, South Africa

e-mail: barney.jordaan@ vlerick.com 


\section{Introduction and Status Quaestionis}

\subsection{Structure of the Chapter}

The structure of the chapter will be as follows. In the first section of the chapter the need for the essay and a cursory Status quaestionis will be provided. Secondly the conceptual and technical framework of the paper will be sketched, by providing a theoretical discussion of metaphor theory in which we will specifically draw on the insights of Lakoff and Johnson (2003) who are considered world leaders in conceptual metaphor theory. Within the context of the research group/book, and the intersection between leadership, spirituality and discernment, we will provide some perspectives from research on the phenomenon (and philosophy) of hope, drawing on Richard Rorty's insights, and its possible relation to mediation. ${ }^{1}$ Thirdly, these insights will be brought into dialogue with mediation as academic discipline within jurisprudence, i.e., how metaphors (of hope) and the underlying philosophy of hope, could influence the mediation process. Since the social-constructivist epistemology is used, the meta-theory of language and meaning being used here serves as the conceptual frame underlying the scientific approach of the argument. Secondly, from an epistemological point of view, spirituality ${ }^{2}$ and the perspective of hope serves within the post-foundational ${ }^{3}$ frame of reference of the authors and their

\footnotetext{
${ }^{1}$ See the renewed interest in some circles of business to reflect on hope. See Borman's (2016) "The world book of hope" and also Van den Heuvel and Nullens' (2018) book "Driven by hope: Economics and Theology in Dialogue."

${ }^{2}$ The term "spirituality" has a wide range of definitions (see Nullens and Barentsen 2014). For us spirituality is defined within the awareness of our embodied realism and embodied cognition which calls for the Other to extend our cognition and participate relationally with others (or the Divine Other) in a process of co-creation of meaning, significance and values, growth and transformation (see Waaijman 2002). A Hermeneutic of hope, which we will discuss at the end of the chapter, is thus a form of spirituality.

${ }^{3}$ For the definition and understanding of post-foundational, and also for inter-and-transdisciplinary approaches, see Van Huyssteen (1997). We understand it as an epistemology that is hesitant to build on an assumed authority, but rather in dialectical fashion argue in favour of a certain rationale for acts denoting a rejection of an assumed or given authority for a specific belief or action but arguing, in dialectical fashion, for a rationale for action or belief in a social-constructivist context. This includes in our view also a sensitivity to contexts in which dialogue should take place and inclusivity be promoted. This does however not exclude the multi-facetness of identity of the researcher(s) who might from a Dialogical-Self Theoretical perspective (see Hermans and Hermans-Konopka 2010) embody certain forms of social identity which might adhere to values within certain socio-religious groups. The construction of narratives play an important role in discourses and identity. Within narratives, one also finds metaphors that guide and shape the discourse of a narrative and for that reason some even speak of "narraphor" [see the term used by Nelus Niemandt (2018), influenced by Sweet (2014, p. 91)]. "Narraphor" is understood as "At the core of who we are, we crave a narraphor. A narraphor is a story made with metaphors that help us understand the world, ourselves, each other and our community." Subsequently, I (J. Kok) have coined the term "metanarraphor" which will be discussed below. [One of the blind peer reviewers of this article made the following remark which is worth noting for further discussion and research: "Freud, and most recently Steenkamp, point out how much metaphors (and what you call
} 
Fig. 1 Inter-andtransdisciplinary dialogue

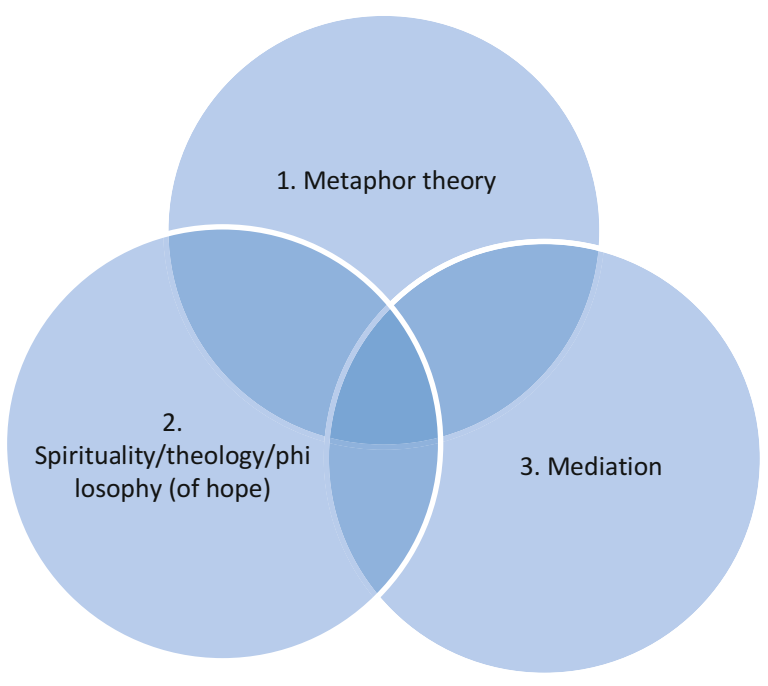

trans-disciplinary engagement. Subsequently, attention is turned to the discipline of mediation with an example of a concrete case study which will be discussed with the aforementioned theoretical presuppositions. Graphically the inter-and-transdisciplinary ${ }^{4}$ structure of the article could be illustrated as follows (Fig. 1).

\subsection{Lifelong Learning Organizations: From Unconscious Incompetence to Unconscious Competence}

In Business management and in other disciplines like theology, in this case, learning organizations (a term coined by Peter Senge) ${ }^{5}$ aim to continuously facilitate transformation and growth of their staff. ${ }^{6}$ The research gap this article wants to address

narraphors) are inter-translators of trauma-induced psychological content. It is evidential, and I agree with the formulation 'that we crave a narraphor'. The craving, though, signals a projection. Describing metaphors being 'at the core of who we are' to me expresses the observation of the prevalence of trauma in the human condition, but would not be an ontological statement of human nature"].

${ }^{4}$ By inter-disciplinary we mean discussions between different subfields within on discipline, for instance theology. This would entail discussions and collaboration between systematic theologians and practical theologians for instance. Transdisciplinary discussions would for instance entail engagement between practical theologians and neuroscientists or quantum physicists-disciplines that would normally not work together on a particular research question. In this article, the authors bring several disciplines in dialogue with each other.

${ }^{5}$ See Senge's (1990 and 2006) book on The art and practice of the learning organization and also Senge's insights in The Firth Discipline (2006).

${ }^{6}$ As one of the peer reviewers of this article remarked, organizational psychologists point that out that it is important for leaders, and in this case mediators, to do sufficient self-work to understand their own shadows and emotional triggers to ensure countertransference is limited. In this regard see 
lies on the theoretical basis of the inter-and-transdisciplinary dialogue between jurisprudence (mediation), theology and philosophy, and social science about the topic of mediation. Jordaan (2013, ad loc), ${ }^{7}$ following Burch's four stage learning model, ${ }^{8}$ remarks that it is important for mediators and negotiators to become aware of their unconscious incompetence, i.e., the fact that they are not always necessarily explicitly aware of the theoretical basis of their negotiation and mediation practice and that they could become even better and more effective in what they do. The problem here is that unconscious incompetence also limits the growth of the mediator. By means of ongoing practice and inter-and-transdisciplinary dialogue, exposure to a proper learning cycle, a mediator could enter a stage of conscious incompetence, i.e., when one is exposed to deeper knowledge and confronted with one's own epistemological and theoretical basis of mediation and aware of one's own gaps and alternative approaches available. ${ }^{9}$ This entails a phase of "deconstruction." 10 When one then goes through this stage, one could eventually become consciously competent, i.e., when one has consciously learned and practiced new methods, approaches and ways of thinking (theory) about mediation. Then, eventually one moves into the stage of becoming unconsciously competent, i.e., when one has integrated the newly acquired skills and theory by means of reflection and constant practice. $^{11}$

In the next section of the paper we will reflect on theory, that is, to stimulate a process of becoming conscious of their incompetence.

\subsubsection{Inter-and-Transdisciplinary Discernment in a Superdiverse and Supermobile World}

\section{Sketching the Backdrop/Relief/Setting the Scene}

We live in one of the fastest changing times in history, amidst a digital, communication and travel revolution which some consider to be as significant as the transition

Kegan (1982) who could be considered to be in the constructive-developmental tradition (vias a vis humanistic and existential-phenomenological [like Buber, Rogers, etc] and the neo-psychoanalytic tradition [like Anna Freud, Erik Erikson, etc]). Kegan (1994) was very much influenced by dialectical philosophy and psychology.

${ }^{7}$ These perspectives of Jordaan (2013, ad loc) was taken from his insights in the "Maximizing Value in Negotiations Programme" hosted at the Graduate School of Business at the University of Cape Town. See https://youtu.be/poiST7IpZpw accessed on 02 February 2018.

${ }^{8}$ See Davis, Leary (2012). Competence as Situationally Appropriate Conduct: An Overarching Concept for Lawyering, Leadership, and Professionalism. Santa Clara Law Review 52(3):725-793. Available at https://digitalcommons.law.scu.edu/cgi/viewcontent.cgi?referer=https://www.google. be/\&httpsredir $=1 \&$ article $=2715 \&$ context=lawreview .

${ }^{9}$ See Kegan $(1982,1994)$ for the stages of ego development.

${ }^{10}$ On the importance on generalizations and the "pictures" or "mental models" we create and according to act from, and the necessity to become personally aware of these and communicate these effectively to co-workers, see Senge's (2006) book Third Discipline.

${ }^{11}$ E.g. keeping e.g., a negotiation ad mediation journal, and over a long time practicing the newly acquired theory and practical skills consciously until it becomes integrated and part of the unconscious competence skill set. 
between the middle ages and the modern word or the dawn of the industrialized world. Our time is characterised by superdiversity and supermobility, which in Business Studies we refer to as resulting in a VUCA (Volatile, Uncertain, Complex, Ambiguous) world (Barentsen and Kok 2017, pp. 7-10; Van den Broeck and Jordaan 2018, p. 12). ${ }^{12}$ The term "superdiversity," a term which originated in the social sciences, was coined by Steven Vertovec ${ }^{13}$ in 2005 and appeared for the first time in an academic article in 2007. His 2007 article on Ethnic and Racial Studies, ${ }^{14}$ and the term superdiversity has since been used widely in different fields. ${ }^{15}$ Superdiversity refers to diversity within diversity (Barentsen and Kok 2017, pp. 7-8). Thus, a form of "diastratification"16 appears within one and the same family for instance, where some members were born in a different country, have a low competency to speak the local language of the host country while others within the same family might have been born and socialized within a liberal democracy and embody a Western conceptual framework as part of their social identity complexity. ${ }^{17}$ After some years they may be highly educated and earn a high income over and against some of their family members who might be dependent on the host country's social system, for instance. The implication is often that the legal statuses between family members might be different. This is what Vertovec means by superdiversity-which is diversity and complexity within diversity (and complexity). In this latest book Geldof (2016) correctly argues that diversity within diversity will increase and be characteristic of the twenty first century. The latest research Geldof (2016) points out, that has been done on population composition in the EU capital Brussels for instance, indicates that circa $66 \%$ of residents have a migration background. Soon to follow the statistical tendency is Antwerp where the majority of citizens will soon be those having a migration background. Thus, we will increasingly find Europe to be a context of "Ethnic-cultural (super)diversity." This will of course shape the future of our society and the need for skills to mediate and negotiate conflict will grow.

Against the background of a VUCA world characterised by superdiversity, scholars and practitioners increasingly become aware of the need for inter-andtransdisciplinary research. Rather recently (2011) the Carnegie Foundation reported on research that has been done on the need for inter-and-transdisciplinary intersection between Business Studies and other disciplines in a study "Rethinking

\footnotetext{
${ }^{12}$ Van den Broeck and Jordaan (2018), The Agile Leader's Scrapbook, LannooCampus, Leuven.

${ }^{13}$ Vertovec was at the time involved at the Max Planck Institute for the Study of Religious and Ethnic Diversity. See http://www.mmg.mpg.de/departments/socio-cultural-diversity/researchfocus/ retrieved 22 February 2018.

${ }^{14}$ Vertovec, Steven (2007). "Super-diversity and its implications." Ethnic and Racial Studies. 30(6): 1024-1054. On 22 February 2018 the article had been cited 2951 times, which proves the impact factor of the article. On a Google search the term super-diversity reported 190 million hits on 31 March 2018.

${ }^{15}$ Geldof, Dirk (2016), Superdiversity in the heart of Europe, Acco Uitgewerij.

${ }^{16}$ Jennifer Slater, from UNISA was the first person who made me aware of the term "diastratification" at a conference in Leuven on 29-30 April 2016.

${ }^{17}$ On social identity complexity theory, see Roccas and Brewer and also Kok (2014) on social identity complexity.
} 
Undergraduate Business Education: Liberal Learning for the Profession" (Colby et al. 2011). One of the outcomes of the research was that a significant amount of business schools in the United States tend to focus on "one-dimensional and specialised courses of study." After the international economic crisis in 2008, scholars and practitioners reflected on the "need (for) entrepreneurs (to) consider the consequences of their activities and who understand the connections between business activities and society." Consequently, the influential Carnegie Foundation deliberately aims to include in their business curriculum, perspectives and insights from human/social sciences. This tendency is also seen in the "European Haniel Program in cooperation with HSG and CBS," and others like the Copenhagen Business School follow educational programs and curricular design that aim at inter-and-transdisciplinary research. ${ }^{18}$

In the field of mediation and negotiation studies, and in the courses presented in the MBA programs in Europe and the U.S. these challenges are inter alia addressed by engaging in inter-and transdisciplinary research, conferences, expert seminars and joint publications. ${ }^{19}$ From the perspective of mediation, this development has proven fruitful for scholars from different disciplines and for practitioners alike.

Below we will provide some examples and further reflect on metaphor theory and a philosophical approach to hope and how it could help mediators to enrich their theoretical approach and skillset.

\section{Insights from Metaphor Theory in Mediation}

Mediation could be defined as a social process whereby a third party (mediator) assists and facilitates individuals or groups in a context of conflict to find win-win solutions. $^{20}$

At the world's leading ${ }^{21}$ Dispute Resolution Program hosted at Pepperdine's Strauss Institute for Dispute Resolution, ${ }^{22}$ scholars and practitioners have for some years already mentioned the importance of narratives ${ }^{23}$ and metaphors in

\footnotetext{
${ }^{18}$ Source: https://www.haniel-stiftung.de/en/promoting-future-generations/the-european-way accessed 19 February 2018.

${ }^{19}$ See for instance the research project on hope between the Erasmus University Rotterdam and the Institute of Leadership and Social Ethics in Leuven (see https://www.etf-ilse.org/our-projects-andresearch/ accessed on 08 March 2018).

${ }^{20}$ See Noce et al. (2002).

${ }^{21} \mathrm{See}$ https://law.pepperdine.edu/straus/ for the announcement of the 2018 award for the best U.S. dispute resolution program accessed 01 March 2018.

${ }^{22} \mathrm{See}$ https://law.pepperdine.edu/straus/ accessed 1 February 2018.

${ }^{23}$ Hansen $(2004$, p. 1) remarks "In mediation, the conflicting parties' stories act like 'theories of responsibility,' which construct the logical, causal linkages between actors, their actions, and outcomes." "People can actually be said to think in terms of stories and their constituent parts (the themes, roles, and plots), which work together to create a system of meaning around particular
} 
mediation. ${ }^{24}$ Thomas Smith (2005, p. 343), a mediator from Colorado, is correct when he argues that metaphor:

[O]perates covertly to gain tacit agreement on direction, means, and ends without full description or rationale. It constrains a discussion, focusing on certain concerns while masking others. Becoming consciously aware of the metaphors commonly used during negotiation offers valuable insights into meanings not overtly discussed. This awareness helps reveal intentions and implicit evaluations while also illuminating obvious areas for mutual gain.

$\mathrm{He}$ is also correct in suggesting that the dynamics of metaphor could be particularly helpful "to reinforce rapport, to persevere in negotiating, to reflect and query usefully, and to explore and propose different options" (Smith 2005, p. 343).

It is of utmost importance that a mediator as leader in a process of mediation not only develops the ability to understand the dynamics or structural properties of metaphor but also ways in which to construct and deconstruct meaning by means of analysing the way in which particular metaphors frame a discourse and also determines the boundaries within which possibilities could be created. ${ }^{25}$ Furthermore, in negotiation an important skill to master is the (psycholinguistic) ability to analyse and clarify meaning behind the words of discourse participants in an effort to ascertain implicit concerns and ways in which possibilities for mutual gain (win-win situations) could be negotiated. In this regard, inter-and transdisciplinary insights from conceptual metaphor theory, promises to provide valuable insights. ${ }^{26}$

In a recent business meeting one of us observed the following metaphorical frame in the discussions between discourse participants referring to Brexit:

The unfortunate divorce between us and England also effects the relationships with the in-laws.

I suppose we would not be enjoying tea in the garden soon.

The relationship is stuck and we are parting ways-there is simply no hope on the horizon.

It is interesting to note that the particular person interpreted Brexit within the metaphorical frame of a divorce between a husband and a wife and the subsequent estrangement of relations involved in the process. From a socio-cognitive and critical-discourse analytical perspective it could be argued that the discourse participant in this meeting projected certain dimensions, and the frame of a divorce unto

people and events. The stories that one constructs fit into a wider web of stories relating to other stories created by the same individual, to stories created by members of one's social network, and even to cultural stories on a societal level." See Hansen (2004).

${ }^{24}$ See Lynne J. Cameron (2007, pp. 197-222 accessed from http://journals.sagepub.com/doi/abs/ 10.1177/0957926507073376? journalCode=dasa). In her article, Cameron "investigates emergent patterns of metaphor in reconciliation talk. .." and also the "identification of linguistic metaphors and works recursively between levels of discourse, revealing how micro-level negotiation of metaphors contributes to emergent macro-level metaphor systems."

${ }^{25}$ Discourse is understood as a social practice in linguistic form (We dó things through words).

${ }^{26} \mathrm{See}$ https://www.haniel-stiftung.de/en/promoting-future-generations/the-european-way accessed 19 Feb 2018. 
the diplomatic (and economic) context. One problem with this metaphor is that it immediately frames the negotiations as adversarial. The frame is likely to impact on the negotiators' approach to the process-i.e, positional rather than collaborative; their tactics or behaviors during the process of negotiation and thus also on the quality of the outcomes they achieve (if any).

The question of course is whether this particular metaphorical frame is at all adequate and whether it will not perhaps limit the possibilities of the negotiation process and influence the discourse between the leaders. Instead of simply uncritically engaging within the frames of this particular discourse and the metaphor being used here, the negotiators and leaders around the table could perhaps consider to reflect critically on the use of this metaphor in this situation. Secondly, by becoming aware of the dynamics of metaphor, leaders, mediators and negotiators could use insights from metaphor theory to build rapport with discourse participants and also steer the direction of discourses in the negotiation process in a more informed (and sophisticated) manner. Different cultures embody different values, and that is often expressed in deep and surface (cultural conventional) metaphors. As described above, in a context of superdiversity and supermobility, which is characteristic of the VUCA world we live in, the negotiator and mediator's ability to reflect critically on language use and meaning by discourse participants becomes even more desired, if not essential. ${ }^{27}$

In the following section we will discuss some salient conceptual and theoretical aspects to buttress the aforementioned scenario and need for deeper understanding of metaphor theory.

\section{Conceptual and Theoretical Discussion}

\subsection{Understanding the Social-Constructive and Socio- Cognitive Critical Discourse Nature of Language}

Some (like Rooney 2015) go so far as to argue that "[T]he mediator is the most powerful person in the room, given his or her control over the process. The mediator's process calls (e.g., whether to meet in private or plenary sessions only); the terminology he or she uses; proposals he or she might make to the parties all have the potential to alter the course of a dispute." This makes it even more important for mediators to be aware of their role, their frames (about the problem, people and process aspects of the dispute) and how these might affect the course of a dispute and, ultimately, the parties themselves. Rooney puts it as follows: "The mediator's presence in the room changes the dynamics in the relationship between the parties. .

\footnotetext{
${ }^{27}$ On superdiversity and supermobility, see Barentsen, Van den Heuvel and Kessler (2017), especially on "Increasing Diversity: Loss of Control or Adaptive Identity Construction" and the dynamics thereof.
} 
The challenge is to work internally on ourselves for it is through this endeavour that we have the most profound effect on those around us both professionally and privately. We cannot afford to be blind to this power." 28

Specialists in socio-cognitive critical discourse analysis like Fairclough correctly illustrate that when discourse participants utter words in an effort to communicate meaning, they draw from/on social cognitions or mental maps. We could thus speak of a form of intertextuality of discourse, i.e., that we not only draw from different layers of meaning "out there" but that our utterances are also multi-layered in particular contexts on the level of interdiscursivity. The latter term wants to express the reality that we dialectically draw on multiple discourses and that in our microexpressions, we take part dialogically in larger macro-socio-political discourses. Thus, there is a dialectical process taking place as we engage with different layers of discourses in society or in a group. In other words, as we take part in the construction of meaning through words, we not only produce but also consume texts by means of drawing from shared and assumed knowledge in our culture which is based on our habitus. Habitus is defined as the system(s) of embodied dispositions, tendencies, etc., which we have internalized from our social world and have become a form of sensus communis. As Bourdieu has argued, it manifests in our hexis (body posture, mannerisms, accent, taste, habits, perceptual schemes and mental habits, etc). The point here is that from a socio-cognitive perspective, what we say draws from existing social maps of knowledge which we in some form reproduce through our communicative actions. ${ }^{29}$ Furthermore, as Bourdieu has showed, communicative action is mostly "contaminated" by power dynamics, i.e., that by our words and our metaphors, we position ourselves vis a vis another, in a particular way. A mediator should in other words also have the heuristic tools to be sensitive to the manner in which power relations are structured, embodied, maintained/sustained or transformed in the process of negotiation. ${ }^{30}$ Fairclough (1992, pp. 65, 126, 124-130) has shown that particular power interests are either reproduced or transformed in and through the way we use language and discourse in a given context. As we enter as patients the consulting room of a medical specialist, the mere context positions us in a certain hierarchical relational dynamics. We draw on our habitus and play our respective roles in that discourse context. The social system and the context in other words determines and shapes the nature of the discourse and relations. People aware of this might decide to either reproduce existing discourses and social (power) positioning or decide to challenge and transform the social power relations and meaning. The mediator leads a process of negotiation, and for this reason, he/she needs to be skilled in analysing these

\footnotetext{
${ }^{28}$ Rooney (2015).

${ }^{29}$ See in this regard also Steenkamp (2018, p. 81) for the way in which social maps which we internalize from an early age, are created and "directly shape the neurobiological state of our infant brain" from an early age with implications for the way we shape our identity and habitus.

${ }^{30}$ See in this regard Fairclough's work on Language and Power (1989), Discourse and Social Change (1992), etc.
} 
complex discursive elements in a given discourse context and aim to become aware not only how people intertextually draw on existing "mental maps" (Fairclough 1992 , p. 82) but also wise in how to steer discourses into the direction of a win-win outcome.

\subsection{Understanding the Dynamics of Metaphor}

The study and critical reflection on metaphor is an ongoing process. Classic scholars for instance provide helpful insights on Aristotle, who wrote extensively on the nature of metaphors. In his contribution to the debate, negotiator Thomas Smith (2005) remarks: "Writings at least as old as Aristotle define metaphor as talking about one thing in terms of another." But here Smith lacks depth in his approach probably due to the fact that he mainly makes use of secondary sources and have not consulted Aristotle as primary source directly. However, already in ancient times, a difference was pointed out between a metaphor, a simile, a comparison and a symbol. Also, they reflected critically on the function of words by the speaker. Functionally speaking, there is a difference between a surface metaphor and a deep metaphor. There is a difference between [see Lyons ${ }^{31}\left(1986\right.$, p. 216)] ${ }^{32}$ the understanding of the functional dynamics of metaphor and figurative meaning, between a metaphor and a so called proper comparison.

Let us provide the following examples from a recent case ${ }^{33}$ where an employee claimed constructive dismissal. ${ }^{34}$ The mediator played an important role in the resolution of the dispute with a successful (win-win) outcome for all parties inter alia by means of his/her use of metaphor theory and socio-cognitive discourse analysis $^{35}$ :

\footnotetext{
${ }^{31}$ Lyons as referred to by Van der Watt (2009, p. 305).

${ }^{32}$ Van der Watt (2009, p. 306).

${ }^{33}$ All persons fictitious disclaimer: "The story, all names, characters, and incidents portrayed in this (re)production are fictitious. No identification with actual persons (living or deceased), places, buildings, and products is intended or should be inferred."

${ }^{34}$ See http://www.legislation.gov.uk/ukpga/1996/18/contents. The employee had some knowledge of employment law [and the terms of constructive dismissal (see Employment Rights Act 1966 section 95(1)c)] and therefore was aware of certain forms of unethical behaviour/discrimination occurring in the workplace based on emotional interpersonal conflict between the respective employee and his/her superior. This was also evidenced in the negative performance evaluation process, although the employee outperformed set targets. An oral negotiation process in the recruitment phase, was also not honoured by the employee, leading to damage or breach in trust because of unilateral contract changes by the employer [see ERA96 s98(4)]. Since this constituted a legitimate dispute, a mediator was called in.

${ }^{35}$ The term "constructive dismissal" is a terminus technicus used in employment law to refer to the voluntary resignation of an employee, as a direct result of what he/she experiences as an hostile environment, created by an employer. This might include the experience of unfair treatment, unreasonable work-related demands, or possible intention by an employer to force an employee
} 
\#a. Employee before and during mediation: "Barry, my boss, is stubborn like a horse with blinkers/blinders. I try to talk to him but gained no ground and in the process he attacks my integrity and underestimates my experience. How dare he refer to me as an 'African' and that 'Up here' we do it the 'European' way. Or the fact that I am not 'integrated' well enough. It is blatant racism and discrimination, especially when put in an email copied to colleagues, or discussed around the staff room. I feel that the time has come for our paths to separate, for I have no hope."

\#b. Employee after mediation [endorsement]: "The mediator was a catalyst. ${ }^{36}$ $\mathrm{He} / \mathrm{she}$ created a positive effect in restoring the trust and power balance."

Within these two extract examples one finds several metaphors which need to be deconstructed. In example (a) the "point of comparison" framework is more closely determined than example (b). The point being made is the "stubbornness" of the "opponent" and in the process of conveying this message functionally, the boss (tenor) is compared to a blinded horse ${ }^{37}$ (vehicle), with the function of communicating the point of "stubbornness." Also note that there is a certain power dynamics at play here, because the parties in this process are hierarchically positioned in a lower and higher position in the particular context from the perspective of their discourse. The employee experiences that the employer views his/her African identity as inferior to that of the Westerner and that he/she is discriminated against and feels powerless against the "inflexibility" or "obstinacy" of the employer. The metaphorical frame of implicit "distance" and difference in class, is underlying the use of the words "up here" and "down there." Below we will show how this way of speaking is a performative act in which power is exercised and some positioned "lower" than others on the level of competency or quality based on what we will refer to as "metanarraphor."

\footnotetext{
to resign. If this is proven, it would technically constitute a case of constructive dismissal (See Kennedy 2015). If the claim is valid, the employee could make legal claims against the employer. In the case of the UK, constructive dismissal is explained and defined in the Employment Rights Act 1996 section 95(1)c. "The notion of constructive dismissal most often arises from a fundamental breach of the term of trust and confidence implied in all contracts of employment. In order to avoid such a breach '[a]n employer must not, without reasonable or proper cause, conduct himself in a manner calculated or likely to destroy or seriously damage the relationship of trust and confidence between the employer and the employee.' Whilst a breach can be of the implied term of trust and confidence, a fundamental breach of any of the express or implied terms of a contract of employment is sufficient." http://www.legislation.gov.uk/ukpga/1996/18/contents visited 22 Feb 2018.

36، The negotiator is a catalyst" is a copulative metaphor [negotiator is tenor (tenor is the lexical item which one can take literally and "on which the metaphorical meaning is applied"); Catalyst is the vehicle, (i.e., the "lexical item generating the metaphorical meaning") See Van der Watt (2009), p. 309]. Van der Watt also makes use of (and prefers) "focus" and "frame," i.e., "frame refers to the literal situation, while focus refers to the word(s) that generated the metaphorical meaning."

${ }^{37}$ This could be seen as an intergenerational and cross-cultural metaphor. One still see this image when tourists are visiting Brugge in Belgium or Vienna in Austria alike. In South Africa, for instance this image and metaphor is also used and was influenced by the use of blinkers for horses in (British) colonial times.
} 
On the other hand, example (b), is much more complex in nature. The reason is that from an inter-discursive perspective (especially from a socio-cognitive level discussed above), there are multiple ways, and thus a complexity of possible semantic qualities/relations between the lexical items in which the source domain and the target domain are compared. In a VUCA world characterised by superdiversity and supermobility with clients representing diverse backgrounds, this could become a complex analytical task. According to Van der Watt (2009, p. 308), one can think of explaining the relationships between these items by means of the image of a "semantic sieve," looking at all the qualities of both lexical items that "fall through" and are related/overlap. By looking at these shared qualities one can discern the dynamics of the points of interaction which Van der Watt calls "the system of associated commonplaces" which form the analogical basis by which means interpretation is made and meaning constructed. In most cases, there would be points where a target and source domain share qualities or "simultaneous similarity" and where they do not "simultaneous dissimilarity" (Van der Watt 2009, pp. 308-309). Important to note is how the meaning of metaphors used by discourse participants are to be understood? For metaphors are in nature relatively "open" as discourse participants draw comparative connections.

For this reason, one should carefully also look at the cohesion within a body of literature or in a discourse structure by looking at the following (here we are following/drawing from Van der Watt 2009, p. 313):

- Words which are thematically related, for instance, sun, light, sunrays, dawn, dusk, dew, etc.

- Repetition of words which indicates that the author is building on and expanding a particular image.

- Stylistic features, for instance chiasmus, parallelism etc.

- Contextually related coherence within a particular frame, for instance in hospitals where you have sick people, doctors, ambulances, waiting rooms, operating theatres, nurses, scrubs, etc.

By means of these methods one could also determine the nuances and explore the "emotional meaning carried by the metaphor" (Van der Watt 2009, p. 313).

Lakoff and Johnson (2003) explained some of the results of research that has been done in cognitive neuroscience and the relation to metaphors. The latter points out that metaphors are always embedded in a particular frame of reference and also ipso facto a result of an embodied experience.

Lakoff and Johnson (2003) and Lakoff (2009) often uses the following examples: Firstly, it is important to note the importance of frames. For instance, when entering a hospital, that space/frame would be associated with reception desks, nurses, doctors, operating rooms and scalpels. Discourse participants would know that something is wrong from the perspective of the accepted frame if a patient is given a scalpel and asked to operate on a doctor. It simply does not fit the frame. Apart from frames, metaphors are also related to embodied experiences, and there is a significant amount of similarity between cultures because of this embodied experiential reality. When a container is filled with water, we observe the content being 
filled from outside into the container which makes it full. Thus, more water means that we observe vertical increase in level: Thus, more is up and less is down. Accordingly, as Lakoff points out, we would speak of "stock prices going through the roof" with the presupposition of vertical increase. Secondly, the metaphors we use for expressing whether someone is a "warm" person is directly related to experience of physical warmth in close relationships. We also use metaphors to explain emotions like "I am boiling" (for anger) which has a biological experiential basis. Anger is related to the physical increase in blood pressure which leads to increase in body temperature, within the embodied experience of the body as container. Lakoff also often refers to the following example, from his time at Berkeley as this theory was developed. The expression: "Our relationship is stuck and we are parting ways" is embedded within the frame of relationships as journeys with destination(s). The conceptual framework of relationships as journeys, is embedded within the framework of linear thinking of movement from point a to point $b$. Within this frame of "love is a journey" it is thus possible to combine several ways of expressing metaphors and images related to this frame. For instance, "The relationship is on a bumpy road; the wheels are spinning; from here on it will be downhill; hope is on the horizon, etc." These are all examples in which the root metaphor "relationships are journeys" are expanded within the frame of conceptual mapping made possible by the root metaphor.

Metaphors can also function by means of analogy. For instance, if $\mathrm{V}$ is to $\mathrm{W}$ as $\mathrm{Y}$ is to $\mathrm{Z}$ and $\mathrm{A}$ is to $\mathrm{B}$ like $\mathrm{V}$ to $\mathrm{W}$, then $\mathrm{W}$ could be analogical to $\mathrm{Z}$ and $\mathrm{V}$ to $\mathrm{A}$. We could argue that old age (V) stands in a relationship to life's journey $(\mathrm{W})$ as winter (Y) stands to seasons (Z), or dusk (A) to day (B). Thus, we could speak of old age as the dusk of life's journey, or winter as day's dusk. "My journey is entering the chill of days' dusk" is an analogical metaphorical expression that combines the frames of "life as journey" and embodied experience of winter/cold and the slowing down of "life" within the perspective of a linear frame of distance and movement in time from young to old.

The power of metaphor is that the interaction between a source domain and a target domain leads to a creative process of bringing together elements which are not normally brought together in a particular way, creating a new force of meaning. On the other hand these metaphors share particular frames which are rather generic and the apparent connections between communities expressing these metaphors perhaps not that significant. Halstead (2003, p. 83) remarks: "Metaphors are both motivated by and constrained by common patterns of bodily experience and experience of the social and natural environment. .." Metaphors are thus a "fusion of the imagination and embodied experience..." and "grounded in human embodied experience..." Johnson (2005, p. 159) ${ }^{38}$ also agrees and points to the importance of empirical data, illustrating that core analogies "typically come from basic-level-experiences that are

\footnotetext{
${ }^{38}$ Mark Johnson (2005) in "Why metaphor matters for philosophy", Metaphor and Symbolic activity 10,3 , pp. 157-162.
} 

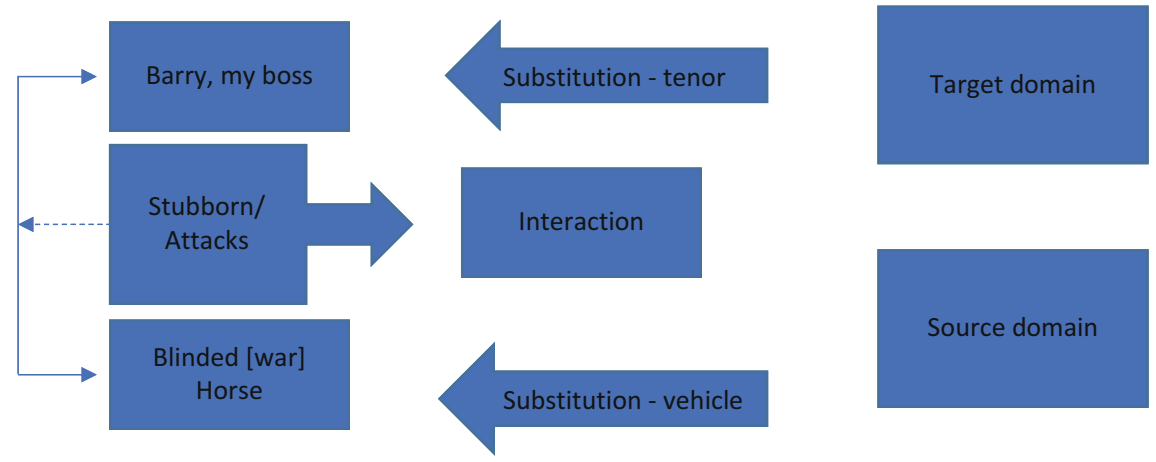

Fig. 2 Schematic representation of dynamics of metaphor

shaped by human beings because of their shared bodily and cognitive makeup and because common features of the environments with which people interact." 39

The metaphorical structure, and transference of meaning from a source domain unto a target domain in the above mentioned examples could be expressed as follows (Fig. 2).

\section{The Mediator as Catalyst of Hope and Win-Win Scenarios}

Mediation is both an art and a science (Jordaan 2013, ad loc). The role of a mediator is inter alia to serve as a catalyst and create trust for a positive win-win situation for both parties in a dispute (Jordaan 2017). Some scholars might criticize the field of mediation for not having a theoretical consensus, but that does not mean that those scholars and practitioners in the field do not have, or take serious various theoretical perspectives in a rather sophisticated manner. ${ }^{40}$ In the process of mediation between the employee and the employer the negotiator facilitated a process in which all the parties could express their feelings by means of what we call "metanarraphor." This term is understood as follows:

We continually construct our identity inter-discursively on macro-meso and micro levels by telling narratives about ourselves in relation to the world at large and the groups we belong to and use metaphors to bind these narratives into coherent meta-narratives about the self-inthe-world. Thus the term "metanarraphor in mediation."

This definition draws on several presuppositions, which range from knowledge of Social identity and Self-Categorization Theory, ${ }^{41}$ Dialogical Self Theory, ${ }^{42}$

\footnotetext{
${ }^{39}$ Halstead (2003, p. 83) also quotes Johnson in a similar argument.

${ }^{40}$ See Noce et al. (2002).

${ }^{41}$ This theory was developed by Tajfel and Turner (see Kok 2017) and illustrates that in-group and out-group dynamics often occur in contexts of conflict and competition. Some people are more loyal to the in-group and will often hold negative views of the out-group. Stereotyping of the out-group is a result of social identity construction.

${ }^{42}$ Dialogical Self Theory (DST) was developed by Hermans and Hermans-Konopka (2010). This theory has shown that "the self" is not monolithic, but pluriform in character. There are different aspects of the self. Thus, myself as academic, myself as son of my father, myself as a negotiator, etc. Sometimes, these different dimensions or parts of the self could be in conflict with one another. The
} 
Ethnicity Theory, ${ }^{43}$ Socio-Cognitive Discourse Analysis, Narrative Counselling techniques, Psychology, etc., which the negotiator had in his/her back pack/tool set.

With regard to dispute resolution, Hansen (2004, p. 2) correctly observes: "For mediation to effectively use the storytelling metaphor and create a cooperative climate among disputants, it becomes necessary to destabilize those 'theories of responsibility' which simultaneously serve to legitimate one's point of view and de-legitimate the point of view of the other party. This leaves conflicting parties with a previously 'closed' interpretation (their story) open to new possibilities and interpretations. This new climate of openness can lead to the genesis of a new account and mutually satisfying interpretations and outcomes."

The analytical tool kit of the negotiator will enabled him/her not only to analyze different discursive elements in the discourse structure of the employee's words, but also to enable him/her to ask certain questions to the employee in a process to facilitate a non-judgmental space of trust between himself/herself and the client.

The mediator for instance became aware that the employee holds on to an underlying meta-narrative (or metanarraphor) in which he/she implicitly believes that Europeans consider Africans to be inferior (refer to "up here" and "down there") which is part of an interdiscursive dominating race discourse ${ }^{44}$ Lakoff and Johnson have illustrated that the notions of "up here" and "down there" are a result of certain embodied metaphors which connotatively and associatively link "up" with better/ stronger and "down" with weaker. In his/her embodiedness, in his/her habitus, he/she carries "African" ethnic identity. There is sufficient research that shows the problematic nature of the subjective lived experience of "African bodies" being discriminated against, ${ }^{45}$ with the (unfortunate) result of what some in the Benelux in the form of an eponym refer to as a calimero-complex. The employee also had many stories that he/she could tell of previous experiences where existential (discriminatory) trauma was experienced. In his latest book on Trauma-Spectrum Manifestation, Steenkamp, a South African Clinical Psychologist, pointed out that trauma is "stored" in the body like pearls to a necklace and past trauma experiences (and memories) are activated in certain circumstances. Steenkamp (2018, p. 181) remarks:

self could also have a distance relationship with aspects of the self from the past, viewing the self from the past as another. Thus, this theory shows that although we embody and belong to different social groups and have different social roles and social identities, these identities are in dialogue with one another. Thus, we embody aspects of the society to which we belong within ourselves. The debates in society are also often debates within the self. This leads to a dialogical self which is not static, but grows and develops over time.

${ }^{43}$ Ethnicity theory, in combination with Social Identity theory (SIT) holds that a particular ethnic group, which is often characterised by a shared language, history, phenotypical characteristics, customs, etc., tend to show favouritism to the in-group in contexts of conflict and change (Kok 2017).

${ }^{44}$ On the interdiscursive "dominating race discourse," see Andreassen and Vitus (2015).

${ }^{45}$ See in this regard the work of Fanon (1967) and the experience of Black people in the West or in African countries with colonial histories in his well-known book "Black Skin, White Mask." Also important in this regard (on the experience of the Black body and decolonialization) is the work of Mignolo (2000, 2007, 2011). 
When we have internal trauma we will be subjected to potential reactivation through futuristic (usually adulthood) external associative activators that are cues reminiscent of previous trauma-activating events. Stress enhances amygdala function, and seeing that the amygdala is involved in implicit memory for emotionally charged events, stress enhances implicit emotional memory for traumatic events.

It is thus deducible that the employee could in fact theoretically easily be activated by words and gestures of his/her European employer which ipso facto entails an emotional response which is extremely complex, for it not only deals with interdiscursive societal discourses on topics like migration and integration, but also with personal trauma which the employee experienced and is reactivated in the current conflict in the workplace. In the process of the mediation, the employee revealed that the employer also reminded him/her of his/her father who was very abusive, strict and stubborn and that he/she vowed never to be the victim again of abuse and oppression. Clearly then, there is a problem behind the problem, and trauma behind the trauma on macro (societal), meso (family) and micro (personal) levels. In this case, several interdiscursive (meta)narratives of trauma, and the emotionally linked metaphors associated with it (narrametaphors) intersected and culminated into a conflict situation in the workplace. As employee and employer we bring our whole selves and therefore conflict also needs to be understood as a multifaceted and nuanced phenomenon. Those sensitive to these complexities can only benefit in the long term.

From the perspective of the words used by the employee, it was clear that another root metaphor, namely that of "argument is war" has been used. Notice the subtle nature of the implicit metaphorical nature of the words "attack" and "gain no ground" in the employee's utterance in \#a. above. Lakoff and Johnson (2003, ad loc) remark:

We saw in the ARGUMENT IS WAR metaphor that expressions from the vocabulary of war, e.g., attack a position, indefensible, strategy, new line of attack, win, gain ground, etc., form a systematic way of talking about the battling aspects of arguing. It is no accident that these expressions mean what they mean when we use them to talk about arguments. A portion of the conceptual network of battle partially characterizes the concept of an argument, and the language follows suit. Since metaphorical expressions in our language are tied to metaphorical concepts in a systematic way, we can use metaphorical linguistic expressions to study the nature of metaphorical concepts and to gain an understanding of the metaphorical nature of our activities.

Naturally then, one could assume that in such a situation of a destructive, ${ }^{46}$ dysfunctional $^{47}$ emotional $^{48}$ conflict situation (vis a vis constructive, substantive

\footnotetext{
${ }^{46}$ In Organizational Psychology dysfunctional conflict is often refer to as destructive conflict which leads to interpersonal animosity and hostility (see Schermerhorn et al. 2011, p. 234 in Organizational Behavior).

${ }^{47}$ In organizational psychology a distinction is made between functional (constructive) and dysfunctional (destructive) conflict: the former refers to healthy conflict that leads to discussions, creativity and individual and team performance, and creative change and development, etc., whereas the latter refers to conflict that break social cohesion, lead to employee disengagement, mistrust, etc. (see Schermerhorn et al. 2011, p. 234 in Organizational Behavior).

${ }^{48}$ In management literature a distinction is made between substantive and emotional conflict: The former refers to disagreements in functional aspects between workers related to work related aspects like strategy, allocation of sources, etc., whereas emotional conflict refers to feelings of mistrust, resentment, animosity towards fellow workers or superiors (see Schermerhorn et al. 2011, p. 232 in Organizational Behavior).
} 
conflict) the primitive fight/flight response of the brain is activated by the parties involved. In this state of hyper-arousal and acute stress response, logical thinking and problem solving do not take place efficiently. ${ }^{49}$ There are many Physiological changes induced by the sympathetic nervous system that show mediators that clients are in a state of hyper-arousal, one being the dilation of the pupils, shaking, flushed cheeks, etc., which are results of catecholamine hormones (e.g. adrenaline and noradrenaline) which prepare the body for fight or flight. ${ }^{50}$ For that reason the mediator can play a significantly positive role in facilitating the client into a safe (r) space where more logical and problem solving reasoning could take place and where the client is "shifted" through the different "stages" of the (primitive) brain. ${ }^{51}$ This is inter alia done by asking open ended questions and asking the client questions that help them to connect with their "metanarraphors," the narratives and the metaphors they live by. The research of Steenkamp (2018) and others have shown that the creation of a non-judgmental space, where narratives and metaphors of clients could be told, has the potential to facilitate a space of "healing" and "integration."

In a superdiverse and supermobile world, social relationships will increasingly be sources of potential conflict as persons from short-term cultures (like the US) and long-term cultures (like Japan); high-power-distance cultures (Japan) and lowpower-distance cultures (Western Europe/e.g. Netherlands) work together (Jandt 1998). In this particular case study, the difference between African values and Western values were also underlying in the conflict. When employers and employees do not understand or have knowledge of these differences, it would lead to conflict and dysfunctional multicultural teams. On the other hand, when these differences are understood and managed from the perspective of adaptive change and constructive conflict, it could be a source of diversity, innovation and creative solutions (Schermerhorn et al. 2011, p. 236).

Often the narratives and metaphors (metanarraphors) we live and lead by limit our possibilities, sense of self, creativity and vision of hope for the future. By understanding metaphorical theory, and by means of the above mentioned toolkit at his/her disposal, the mediator helped the client not only to voice emotions, but also to penetrate deeper levels of past trauma that have been experienced in his/her life. In the process the client was "activated" into a "healing space"52 - a space in which he/she is confronted with the way in which he/she construct and is constrained

\footnotetext{
${ }^{49} \mathrm{See}$ https://www.linkedin.com/pulse/negotiation-brain-game-peter-thompson/ accessed $22 \mathrm{Feb}$ 2018. See Steenkamp (2018, pp. 81-82) for brain physiology and trauma or conflict as well as the work of Damasio $(2000,2010)$.

${ }^{50} \mathrm{See} \quad$ https://courses.lumenlearning.com/boundless-ap/chapter/functions-of-the-autonomic-ner vous-system/ accessed 08 March 2018.

${ }^{51}$ See https://www.healthline.com/health/brain-anatomy accessed 22 Feb 2018.

${ }^{52}$ For the understanding of the terms "activated" and "healing space" in this context, consult the work of Steenkamp (2018, p. 194).
} 
by their narratives and metaphors and how some form of projection is being made on the employer in this particular case.

After the successful mediation process, the employee remarked: "The mediator is a catalyst. ${ }^{53} \mathrm{He} / \mathrm{she}$ created a positive effect in restoring the trust and power balance." 54

Here the copulative metaphor of the "mediator as catalyst" is interesting. The mediator is said to have restored trust and balanced the power dynamics. This is a complex metaphor with many inter-discursive layers of meaning. When trust and power imbalance is felt to have been "restored," a form of hope for collaboration in future is created.

\section{Breaking Bread: A Hermeneutic of Hope and Possibility for Solidarity}

Thus far we have critically reflected on the metanarraphors [(meta)narratives and metaphors] of the employee and the employer in the dispute mentioned as an example case study to illustrate the importance of metaphor theory for mediation. But perhaps it is also important, within the context of this book, with its focus on the nexus between leadership, spirituality and discernment, to reflect also on the metanarraphors that implicitly influence the mediator and the mediation process. Within mediation theory, there are different perspectives and approaches which range for instance from "transformative self-determination" [cf. transformative mediation movement (Baruch Bush and Folger 1994)] and the "mediator as problem solving expert" (see Rooney 2015, pp. 8-9). The broad approach, role and view of the respective mediator will also influence and determine the metanarraphor the mediator will use in his/her general approach to dispute resolution. ${ }^{55}$

Above we have already mentioned that Rooney (2015) argues: "[T]he mediator is the most powerful person in the room, given his or her control over the process. The mediator's process calls...; the terminology he or she uses; proposals he or she might make to the parties all have the potential to alter the course of a dispute." Here we want to further argue that from the perspective of metanarraphor, the mediator's

\footnotetext{
${ }^{53}$ As mentioned above also: "The mediator is a catalyst" is a copulative metaphor [negotiator is tenor (tenor is the lexical item which one can take literally and "on which the metaphorical meaning is applied"); Catalyst is the vehicle, (i.e., the "lexical item generating the metaphorical meaning") see Van der Watt (2009), p. 309]. Van der Watt also makes use of (and prefers) to "focus" and "frame," i.e., "frame refers to the literal situation, while focus refers to the word(s) that generated the metaphorical meaning."

${ }^{54}$ Note the important remark by Greg Rooney $(2015$, p. 2) that "neutral" facilitative mediation and principles like "balanced power" simply do not exist in pure form, but only in theory —and for that reason mere aspirations.

${ }^{55}$ The "Riskin Grid," for instance, illustrates the different roles the mediator can play in a dispute. See Riskin (2003).
} 
hermeneutics of hope might also have a significant influence on the mediation process. ${ }^{56}$ There are different theories of hope, and that also influences one's meta-approach. ${ }^{57}$

Rooney $(2015$, p. 3) makes a strong case, and rightly so, that no mediator is neutral, and that "[Y]ou cannot take the mediator's physical, mental, emotional and spiritual presence in the mediation session out of the relationship equation." In this sense, Rooney (2015, p. 3) points out, in following Ogden (1994), that the mediator as third party in a dispute is the "analytic third" which inevitably has an intersubjective influence on the whole. Ogden (1994) states:

The analytic third is a metaphor for the creation of a mind that has an existence of its own and is capable of thinking in ways that neither contributor to the creation of the third subject is capable of generating on its own

(Ogden 1994; Quoted by Rooney 2015, p. 3).

This by implication means that within the context of mediation, the thoughts, intention and presence of the mediator about the success of the mediation "affects this communal mind" or dimension of the "analytic third" (Rooney 2015, p. 3). Thus, perhaps we need to think about the very metaphors we mediate by and the role that hope plays in the process of leading a process of mediation, in which the mediator is an "equal player in the mediation process" (Rooney 2015, p. 9).

Moti Mironi, experienced mediator and arbitrator and professor of Law at Haifa University always commits to "Breaking Bread" with the parties in a dispute, both as prerequisite for entering into the process and concluding the process, irrespective of the outcome. ${ }^{58}$ Mironi's approach as mediator, as an "analytic third" and his metaphorical notion of "breaking bread" at the start and end of the mediation process, leads to a certain intersubjectivity and creates a "third space" between the parties and the field which is created whenever they share that dialogical space (Ogden 1994; Rooney 2015, p. 3). ${ }^{59}$ The power and dynamics of this metaphor is understandably rather influential in the whole (meta)process as the mediator and the parties co-create mediating moments and movements.

Jordaan (2017) recently observed the importance of hope theory after having been exposed to the work of Snyder (2002), Luthans and Jensen (2002), Cohen-Chen et al. (2014) and Bar-Tal (2001). After a careful study he came to the following conclusion:

My ultimate conclusion from delving into this fascinating subject was that hope theory is in fact intimately connected with what we do as mediators and conflict management

\footnotetext{
${ }^{56}$ There are different theoretical approaches to hope like Snyder, from a positive psychology perspective and others like Rorty from a more philosophical perspective which differs from others like Bloch.

${ }^{57}$ On the theories of hope, see Stanford Encyclopedia referenced above and in the bibliography.

${ }^{58}$ Email exchange on 08 March 2018. Mironi is well-known for using this metaphor in his mediation practice and also in training in the subject. Mironi is a colleague of Jordaan.

${ }^{59}$ Rooney (2015) "Rebooting mediation by detaching from the illusions of neutrality," available at http://ssrn.com/abstract=2564035.
} 
practitioners. Further, I believe that by applying the concept consciously in our work we could potentially enhance the impact of what we do. Jordaan $(2017$, ad loc $){ }^{60}$

Cohen-Chen et al. (2014) illustrated in their research that hope played an important role in the willingness of Israelis and Palestinians to engage in peace talks and fear played an important role in inhibiting possibilities for creative engagement [cognitive freezing; see Cohen-Chen et al. (2014) and Jordaan (2017)].

Jordaan $(2017$, p. 4 ) is correct when he remarks that: "As mediators we are in a particularly privileged position to help disputing parties develop a hopeful disposition with respect to their current conflict and so reap some of the benefits... (e.g., improvement in relationship quality and the management of negative emotions and stress; improved creativity, cognitive flexibility and greater ability to engage in integrative problem-solving").

\section{Rorty on the Hermeneutics of Hope}

As mentioned above, there are many approaches to the theory and philosophy of hope which range from positive psychological perspectives like that of Martin Seligman (2011), Charles R. Snyder ${ }^{61}$ and others (from another angle) like Richard M. Rorty's ${ }^{62}$ hermeneutics of hope. We are inspired by the insights Rorty who worked with "hope as a central element of a hermeneutic" and not per se as an epistemological approach based on certainty and knowledge. ${ }^{63}$ Rorty (1979, p. 318; quoted by Stanford Encyclopedia [SEP] 2017, p. 26) states:

\footnotetext{
${ }^{60}$ Jordaan (2017, ad loc) https://www.linkedin.com/pulse/hope-theory-implications-conflict-man agement-barney-jordaan/ accessed on 08 March 2018.

${ }^{61}$ Charles R. Snyder (1944-2006) was a positive psychologist at the University of Kansas. He is well known for his work on positive psychology in fields of personal feedback, transgression excuse drive and later specialized in research on hope from the perspective of positive psychology.

${ }^{62}$ Richard M. Rorty (1931-2007) was a philosopher at universities like Princeton and Stanford and was educated at Yale and Chicago Universities. He developed strongly the notion that subjective thinking does not equate reality outside of the self. Thus, Rorty did not believe that knowledge represents correctly that/the world which is wholly outside of and independent of the interpreting subject. In this regard he is well-known for his book Philosophy and the Mirror of Nature (1979). He advocated American Pragmatisms (neopragmatism). Later work of Rorty (1989) engage with hope and solidarity, although he was known to be, and heavily criticized for being an "ironist" and radical sceptic.

${ }^{63}$ Of course Rorty disagrees with Bloch on some points, but it is the opinion of the authors of this article that Rorty's view does not in principle exclude in its entirety the notion of Bloch's "Erwartungsaffekte" (expectant emotions like hope and fear) based on his "processual metaphysics" which bases hope on a free human act of "future directed anticipation" (Bloch 1986). The strength of Bloch is that he views open ended "objective tendencies and possibilities in reality" as interacting in some way with "closed" matters of fact, "such that the moment of potentiality surpassing into actuality always opens up opportunities for the interventions of active decision making" (Bloeser and Stahl 2017, p. 19). For that reason he also speaks of the correct way to relate to these "Front" opportunities as nothing less than "militant optimism," i.e., expecting that the "future directed anticipation" could indeed be realized (Bloeser and Stahl 2017, p. 19). Thus, Bloch's notion moves into the domain of what we would call "spiritual," in the sense that a "militant optimism" towards "future directed anticipation" of desires, beliefs and expectations is a form of
} 
Hermeneutics sees the relations between various discourses as those of strands in a possible conversation, a conversation which presupposes no disciplinary matrix which unites the speakers, but where the hope of agreement is never lost so long as the conversation lasts.

Against Rorty as radical ironist and atheist, we would like to argue (by using his own words) that hope is a form of a spiritual/faith/ethical value, which is not always in the first place grounded in knowledge or probabilities, but rather seen as "an attitude by which interlocutors express both their commitment to certain forms of future interaction and their belief in its possibility" (SEP 2017, p. 20). It is a firm belief and "ability to believe that the future will be unspecifiably different from, and unspecifiably freer than, the past" (Rorty 1999, p. 120 as quoted by SEP 2017, p. 20). This opens up the dimension of spirituality mentioned in the beginning of this essay, namely that for us spirituality is defined within the awareness of our embodied realism and embodied cognition which calls for the Other to extend our cognition and participate relationally with others (or the Divine Other) in a process of co-creation of meaning, significance and values, growth and transformation. A Hermeneutic of hope, which we will discuss below, is thus a form of spirituality and transcends the self.

For Rorty, and for the author(s) of this article, hope has an ethical dimension in the sense that it ipso facto entails intersubjective communication and that we are called to dialogue with each other even as "liberal ironists" hopes" in such a way that we witness to the hope and active belief that it is possible to reach agreement and that this form of expectation of future (im)possibility is a reflection of "the liberal virtue of civility" (see Rorty 1979, p. 318) and a source of (possible) mutual solidarity (Rorty 1989, p. 93, 1999, p. 87). In this sense, such a mediator's hope might even be seen as "unjustifiable" due to the fact that it does not require objective foundations (See Rorty 2002, p. 58; SEP 2017, p. 21). Important to note is that Rorty points out that "hopelessness is always based on the absence of a narrative of political progress" which means by implication that "if such a narrative is available this seems to provide rational support for political hope" (SEP 2017, p. 21). This brings us back to the notion of metanarraphor, i.e., the way we think about life and the metanarratives and metaphors we construct and live by. A good

\footnotetext{
"metaphysical possibilities in the world and part of a range of human capacities that make it possible to relate to that which is not yet, but which is already prefigured in the objective potentials of reality" (Bloeser and Stahl 2017, p. 19). See Bloeser and Stahl (2017), "Hope," The Stanford Encyclopedia of Philosophy (SEP) (Spring 2017 Edition), Edward N. Zalta (ed.), URL = https:// plato.stanford.edu/archives/spr2017/entries/hope/.

${ }^{64}$ Rorty differentiates the "liberal ironist" from the "liberal metaphysician." The latter "expects social cooperation to be based on scientific or philosophical insight that penetrates individual idiosyncrasy and aims at the adoption of a universal, final vocabulary that then leads to solidarity" (See Bloeser and Stahl 2017, p. 20 in the Stanford Encyclopedia of Philosophy [from here on SEP]); (see Rorty 2010, p. 93). The "liberal ironist" on the other hand does not hold on to the idea of "a final vocabulary" or some form of intrinsically, universally human communality or basis (SEP 2017, p. 20). Rather, in continuing dialogue and in our "selfish hopes" we may/will find and co-create solidarity being born from shared experiences and shared interests (Rorty 1999, p. 87; Bloeser and Stahl 2017, p. 20).
} 
mediator, even the disillusioned-liberal-ironist legal practitioner often functioning as a mediator, has the ethical (and spiritual) duty to fight for hope as "an expression of the liberal virtue of civility" (Rorty 1979, p. 318). Only when the mediator's own metanarraphor witnesses to the attitude and belief in hope as a sacred space of potential change, does he or she do justice to the insights of modern political philosophy that give hope a central and rightful place in their respective mediatory (and political) thought and actions. For this reason, this fundamentally important attitude and hermeneutics of hope of the mediator in the context of a dispute resolution process is a form of discernment and a form of leadership which is guided towards the possibility of facilitating moments where bread could be broken and communal solidarity be created. The "open" way in which Rorty conceptualizes hope is in other words helpful for mediation as an open ended process. But of course there are many other, even more valuable and applicable conceptions of hope (see e.g. Jordaan 2017). Riskin (2003) calls the mediator the most powerful person in the room. Perhaps that is an overstatement, perhaps not. Be as it may, for the mediator as leader, facilitator and empowering facilitator of disputants in a dispute resolution process, it is wise to be able to discern several options and approaches available.

\section{Conclusion}

In this paper we argued that we are living in one of the fastest changing times in history - a time which is characterised by superdiversity and supermobility. This leads to a VUCA environment which challenges us to become even more sophisticated in conflict management, dispute resolution and discernment. Latest trends in Business Studies and some MBA programs illustrate an increasing need for interand-transdisciplinary engagement to such an extent that we find courses like Spirituality and Entrepreneurship being offered at Business schools in Europe ${ }^{65}$ In this paper we argued that mediators will benefit themselves and the parties to a conflict or dispute if they are equipped with inter-and-transdisciplinary insights like metaphor theory, narrative approaches to counselling (metanarraphor) and insights from philosophers on aspects of hope. This is where leadership, spirituality and discernment engage in creative exchange of possibilities for constructive change towards communal solidarity and conflict management. Not only could those disciplines like theology who are concerned with the "spiritual" and "metaphorical" dimensions learn from those in the discipline of mediation and dispute resolution, but also vice versa. Thus, this chapter wanted to contribute to mediation theory and to the ongoing

\footnotetext{
${ }^{65}$ See for instance https://www.nyenrode.nl/faculteit-en-onderzoek/faculteitsleden/p/shardanandram website visited on 1 March 2018. Prof. Sharda Nandram specialises in Spirituality and Entrepreneurship within the context of the Center for Entrepreneurship \& Stewardship. See Nandram et al. (2010). Others like the well-known Luk Bouckaert in Bouckaert and Zsolnai (2011). Both Bouckaert and Nandram are on the board and steering committee of the European SPES (Spirituality, Economics, Society) Institute (see http://eurospes.org/ visited 09 March 2018).
} 
inter-and-transdisciplinary dialogue between the disciplines mentioned in the article, with the hope that it would stimulate further engagement and research.

\section{References}

Barentsen J, Kok J (2017) Leadership, (super)diversity and identity construction. In: Barentsen J, Van den Heuvel S, Kessler V (eds) Increasing diversity: loss of control or adaptive identity construction? vol CPLSE 5. Peeters, Leuven

Andreassen R, Vitus K (2015) Affectivity-and-race-studies-from-Nordic-contexts. Routledge, Surrey

Baruch Bush RA, Folger JP (1994) The promise of mediation: responding to conflict through empowerment and recognition. Jossy Bass, San Francisco

Borman L (ed) (2016) The world book of hope. Lannoo, Tielt

Bloch E (1986) The principle of hope. vol 3, translated by N. Plaice, S. Plaice and P Knight, MIT Press, Cambridge

Bloeser C, Stahl T (2017) "Hope", The Stanford Encyclopedia of Philosophy [SEP] (Spring 2017 Edition). Zalta EN (ed), https://plato.stanford.edu/archives/spr2017/entries/hope/

Bouckaert L, Zsolnai L (eds) (2011) The Palgrave handbook of spirituality and business. Palgrave Macmillan, Basingstoke

Bar-Tal D (2001) Why does fear override hope in societies engulfed by intractable conflict, as it does in Israeli society? Polit Psychol 21(3):601-627

Cameron LJ (2007) Patterns of metaphor use in reconciliation talk. Discourse Soc 18(2):197-222. Available http://journals.sagepub.com/doi/abs/10.1177/0957926507073376?journalCode=dasa. Accessed 31 March 2018

Cohen-Chen S et al (2014) The differential effects of hope and fear on information processing in intractable conflict. J Soc Polit Psychol 2(1):2915-3325

Colby A, Ehrlich T, Sullivan WM, Dolle JR (2011) Rethinking undergraduate business education: liberal learning for the profession. Jossy Bass, San Francisco

Damasio A (2000) The feeling of what happens: body, emotion and the making of consciousness. Vintage, London

Damasio A (2010) Self comes to mind: constructing the conscious brain. Vintage, London

Davis L (2012) Competence as situationally appropriate conduct: an overarching concept for lawyering, leadership, and professionalism. Santa Clara Law Rev 52(3):725-793 Available at https://digitalcommons.law.scu.edu/cgi/viewcontent.cgi?referer=https://www.google.be/\& httpsredir $=1 \&$ article $=2715 \&$ context $=$ lawreview

Fairclough N (1992) Discourse and social change. Polity Press, Cambridge

Fairclough N (1989) Language and power. Longman, London

Fanon F (1967) Black skin, white mask. Translated by Charles Lam Markmann, Grove Press, New York

Geldof D (2016) Superdiversity in the heart of Europe. Acco Uitgewerij, Leuven

Halstead JM (2003) Metaphor, cognition and spiritual reality. In: Carr D, Haldane J (eds) Spirituality, philosophy and education. RoutledgeFalmer, London, pp 81-94

Hansen T (2004) The narrative approach to mediation. Pepperdine Disput Resolut Law J 4(2): Collaborative Law Article 10

Hermans HJM, Hermans-Konopka A (2010) Dialogical self theory: positioning and counterpositioning in a globalizing society. Cambridge University Press, New York

Jandt F (1998) Intercultural communication. Sage, London

Johnson M (2005) Why metaphor matters for philosophy. Metaphor Symb Act 10(3):157-162 
Jordaan B (2013) "Maximising value in negotiations programme" hosted at the Graduate School of Business at the University of Cape Town. Available https://youtu.be/poiST7IpZpw. Accessed $02 \mathrm{Feb} 2018$

Jordaan B (2017) Hope theory: implications for conflict management. https://www.linkedin.com/ pulse/hope-theory-implications-conflict-management-barney-jordaan/. Accessed 08 March 2018

Kegan R (1982) The evolving self: problem and process in human development. Harvard University Press, Cambridge

Kegan R (1994) In over our heads: the mental demands of modern life. Harvard University Press, Cambridge

Kok J (2014) Social identity complexity theory as heuristic tool in new testament studies. HTS Teologiese Stud/Theol Stud 70(1):9 Art. \#2708. https://doi.org/10.4102/hts.v70i1.2708

Kok J (2017) Drawing and transcending boundaries in the DRC. University of Pretoria UPeTD, Pretoria

Kennedy G (2015) ‘Negotiation', Edinburgh Business School MBA module in Negotiation, HeriotWatt University. Available https://www.ebsglobal.net/EBS/media/EBS/PDFs/NegotiationCourse-Taster.pdf. Accessed 09 March 2018

Lakoff G, Johnson M (2003) Metaphors we live by. University of Chicago Press, Chicago

Lakoff G (2009) https://www.youtube.com/watch?v=Eu-9rpJITY8. Accessed 1 July 2017

Luthans F, Jensen SM (2002) Hope: a new positive strength for human resource development. Hum Resour Dev Rev 1(3):304-322

Mignolo W (2000) (Post)occidentalism, (post)coloniality, and (post)subaltern rationality. In: AfzalKhan F, Seshadri-Crooks K (eds) The pre-occupation of postcolonial studies. Duke University Press, Durham, pp 86-118

Mignolo W (2007) Delinking. Cult Stud 21(2-3):449-514

Mignolo W (2011) The darker side of western modernity: global futures, decolonial options. Duke University Press, Durham

Niemandt N (2018) Competing narraphors in the post-Zuma landscape. Lecture delivered at the opening of the Faculty of Theology, University of the Free State (19 Feb 2018)

Nandram S, Borden S, Margot E (eds) (2010) Spirituality and business exploring possibilities for a new management paradigm. Springer, Heidelberg

Noce DJ, Baruch Bush RA, Folger JP (2002) Clarifying the theoretical underpinnings of mediation: implications for practice and policy. Pepperdine Disput Resolut Law J 1. Available http:// digitalcommons.pepperdine.edu/drlj/vol3/iss1/3. Accessed 1 March 2018

Nullens P and Barentsen J (2014) (see source at http://www.peeters-leuven.be/boekoverz.asp? $\mathrm{nr}=9491)$

Ogden TH (1994) The analytic third: working with intersubjective clinical facts. Int J Psychoanal 75 (Pt 1):3-19

Riskin LL (2003) Who decides what? Rethinking the grid of mediator orientations 9 No. 2 Dispute Resolution Magazine 22, 22 (Winter 2003) and also http://www.adrtoolbox.com/library/riskinsgrid/. Accessed 09 March 2018

Rooney G (2015) Rebooting mediation by detaching from the illusions of neutrality. Available http://ssrn.com/abstract=2564035. Accessed 08 March 2018

Rorty R (1979) Philosophy and the mirror of nature. Princeton University Press, Princeton

Rorty R (1989) Contingency, irony and solidarity. Cambridge University Press, Cambridge

Rorty R (1998) Truth and progress (Philosophical papers, vol 4). Cambridge University Press, Cambridge

Rorty R (1999) Philosophy and social hope. Penguin Books, Middlesex

Rorty R (2002) Hope and the future. Peace Rev 14(2):149-155. https://doi.org/10.1080/ 10402650220140166

Seligman MEP (2011) Flourish. Free Press, New York

Senge PM (1990) The art and practice of the learning organization. The new paradigm in business: emerging strategies for leadership and organizational change, 126-138 
Senge PM (2006) The fifth discipline: the art and practice of the learning organization. Doubleday, New York

Schermerhorn JR, Hunt JG, Osborn RN, Uhl-Bien M (2011) Organizational behavior. Wiley, Hoboken

Smith TH (2005) Metaphors for navigating negotiations. Negot J 21(3):343-364

Snyder CR (2002) Hope theory: rainbows in the mind. Psychol Inq 13(4):249-275

Steenkamp J (2018, forthcoming) Trauma spectrum manifestation. SHIP, Pretoria

Sweet L (2014) Giving blood: a fresh paradigm for preaching. Grand Rapids, Zondervan

Van den Broeck H, Jordaan B (2018) The agile leader's scrapbook. LannooCampus, Leuven

Van den Heuvel SC, Nullens P (eds) (2018) Driven by hope: economics and theology in dialogue, vol CPLSE 6. Peeters Press, Leuven

Van der Watt JG (2009) Reading new testament imagery. In: Du Toit A (ed) Focusing on the message. Protea, Pretoria, pp 305-340

Van Huyssteen JW (1997) Essays in postfoundationalist theology. Eerdmans, Grand Rapids

Vertovec S (2007) Super-diversity and its implications. Ethn Racial Stud 30(6):1024-1054

Waaijman K (2002) Spirituality: forms, foundations, methods. Peeters, Leuven

\section{Internet Sources Consulted}

See Jordaan B (2012) https://www.youtube.com/watch?v=poiST7IpZpw\&feature=youtu.be. Accessed 01 March 2018

See Nandran S https://www.nyenrode.nl/faculteit-en-onderzoek/faculteitsleden/p/sharda-nandram website visited on 1 March 2018

See Lakoff G (2009) https://www.youtube.com/watch?v=Eu-9rpJITY8. Accessed 09 March 2018

See https://courses.lumenlearning.com/boundless-ap/chapter/functions-of-the-autonomic-nervoussystem/. Accessed 08 March 2018

See https://www.haniel-stiftung.de/en/promoting-future-generations/the-european-way. Accessed 19 Feb 2018

See https://en.wikipedia.org/wiki/Constructive_dismissal visited 22 Feb 2018

See https://www.healthline.com/health/brain-anatomy. Accessed 22 Feb 2018

See https://law.pepperdine.edu/straus/ for the announcement of the 2018 award for the best

U.S. dispute resolution program. Accessed 01 March 2018

See https://www.etf-ilse.org/our-projects-and-research/. Accessed on 08 March 2018

See http://eurospes.org/. Accessed on 09 March 2018

See http://www.legislation.gov.uk/ukpga/1996/18/contents. Accessed 29 March 2018

Jacobus (Kobus) Kok (Ph.D; Ph.D) is Professor and Head of Department New Testament Studies at the Evangelische Theologische Faculteit Leuven in Belgium, Extraordinary Professor in New Testament at the University of Pretoria and Research Associate in Greek at the University of the Free State. NRF Y1 rated research associate at the University of Pretoria, South Africa. Kok is also an experienced corporate trainer and facilitator and head of coaching and mentoring at ETF Leuven. He serves on the editorial boards of the Institute of Leadership and Social Ethics, Neotestamentica, Verbum et Ecclesia, In Luci Verbi, etc. Kok authored or edited nine books on topics mainly revolving around social cohesion-the latest being "New Perspectives on Healing, Restoration and Reconciliation in John" published with Brill.

Barney Jordaan (Ph.D.) holds a doctorate in law from Stellenbosch University, South Africa. He is currently professor of management practice (negotiation and dispute resolution) at Vlerick Business School, Belgium. Jordaan is also an Extraordinary Professor at the University of Stellenbosch Business School. Prior to moving to Belgium in 2014 he held a number of academic 
appointments in South Africa. These included 14 years as professor of law at Stellenbosch University and thereafter as professor of negotiation and conflict management at the University of Stellenbosch Business School and the Graduate School of Business, University of Cape Town. In conjunction with his academic involvement, Barney also practised as human rights lawyer in South Africa during the apartheid era before co-founding a consulting firm in 1998 which advises corporate clients on conflict management strategies, negotiation and related matters. He has been involved in the mediation field since 1989 as practising mediator, trainer and coach. He is an internationally certified as mediator with, amongst others, the Centre for Effective Dispute Resolution (CEDR, UK) and the International Mediation Institute in The Hague.

Open Access This chapter is licensed under the terms of the Creative Commons Attribution 4.0 International License (http://creativecommons.org/licenses/by/4.0/), which permits use, sharing, adaptation, distribution and reproduction in any medium or format, as long as you give appropriate credit to the original author(s) and the source, provide a link to the Creative Commons licence and indicate if changes were made.

The images or other third party material in this chapter are included in the chapter's Creative Commons licence, unless indicated otherwise in a credit line to the material. If material is not included in the chapter's Creative Commons licence and your intended use is not permitted by statutory regulation or exceeds the permitted use, you will need to obtain permission directly from the copyright holder. 